\title{
Circulating Osteocalcin is Associated with Time in range and other Metrics Assessed by Continuous Glucose Monitoring in Type 2 Diabetes
}

Jun Liu

Southern Medical University

Yinghua Wei

Nanjing University

Pu Zang

Nanjing University

Wei Wang

Nanjing University

Zhouqin Feng

Southern Medical University

Yanyu Yuan

Nanjing Medical University

Hui Zhou

Southern Medical University

Zhen Zhang

Southern Medical University

Haiyan Lei

Southern Medical University

Xinyi Yang

Nanjing University

Bin Lu

Nanjing University

Jiaqing Shao ( $\square$ shaojiaqing@nju.edu.cn )

Southern Medical University

jun liu

Nanjing Medical University

\section{Research Article}

Keywords: Glycemic control, Time in range, Bone metabolism, Osteocalcin, Type 2 diabetes mellitus, HOMA-IS 
Posted Date: March 7th, 2022

DOI: https://doi.org/10.21203/rs.3.rs-1377743/v1

License: (c) (i) This work is licensed under a Creative Commons Attribution 4.0 International License. Read Full License 


\section{Abstract}

\section{Background:}

Osteocalcin is a sort of protein secreted by osteoblast exclusively囚and new observations have verified that glucose balance can be modulated by it in some ways. TIR has attracted more and more attention as an emerging blood glucose evaluation index. In this study, the association between TIR and the level of circulating osteocalcin was investigated in type 2 diabetes.

\section{METHODS}

376 patients with type 2 diabetes were enrolled in our trail, all of them performed three consecutive days of monitoring. And they were divided into four groups on account of the quartile of osteocalcin. TIR, Time below range(TBR, , Time above range(TAR) and measures of glycemic variability (GV) were assessed for analysing. After a 100g standard steamed bread meal, blood glucose (Glu0h Glu0.5h, Glu1h, Glu2h, GLu3h), C-peptide (Cp0h, Cp0.5h, Cp1h, Cp2h, Cp3h), serum insulin (INSOh, INS0.5h, INS1h, INS2h, INS3h) concentrations at different time points were obtained. HOMA-IS, HOMA- $\beta$ was calculated to evaluate insulin sensitivity and insulin secreting of the participants.

\section{RESULTS}

TIR increased significantly as the osteocalcin level increased between groups $(p<0.05)$. No significant differences were found in gender composition, age, weight, BMl, diabetes duration, $\mathrm{K}+\mathrm{Ca}+$, Creatinine, blood pressure among groups (respectively, $p>0.05$ ). Osteocalcin had positive correlation with TIR $(r=0.227, P<0.001)$, while a negative correlation was presented in osteocalcin and TAR $(-0.229, P<0.001)$. Likewise, osteocalcin was negatively correlated with INSOh, INS0.5h, fasting blood glucose and postprandial blood glucose at any time point after intaking of a standard meal.

Meanwhile, osteocalcin had a negative correlation with the majority of GV indexes including standard deviation (SD), mean blood glouse (MBG), mean of daily differences (MODD), average daily danger range (ADDR). Multiple stepwise regression analysis demonstrated that osteocalcin was an independent contributor of TIR, TAR, and HOMA-IS.

\section{CONCLUSIONS}

Circulating osteocalcin has a positive correlation with TIR, and is an protective factor of TIR and insulin sensitivity in type 2 diabetic patients.

\section{Background}

In the past decades, the quantity of diabetic patients increased from 151 million to an estimated 463 million in 2020[1], and diabetes has been the ninth dominating cause of death in the global area[2]. Identifying type 2 diabetic patients who could profit from enhanced glycemic control was important for 
improving clinical outcome. In addition, the individual uniqueness of the patient was also emphasized in current guidelines of treating for diabetes. HBA1c was deemed to a credible and common biomarker which reflects an average glycemic control condition in the past 2 to 3 months[3,29], and a lines of studies have proved that HBA1c efficiency in diabetes care and clinical application[24, 30]. However, the biggest limitation of HBA1c is that it can not grab short-term glucose fluctuation and seize hyperglycemia or hypoglycemia events daily [4]. Continuous glucose monitoring (CGM) measures glucose concentration in the interstitial fluid during a few days and transmits a more general glucose control condition to user than HbA1c. In 2017, a standardized CGM reporting was recommended by the international in Diabetes Care [5]. TIR, TBR, TAR, and GV were parameters offered by CGM[6], and TIR has been testified to keep a high consistency with HbA1c in many studies[8].In 2019, the ATTD Congress supported TIR as one of the target metrics in glucose controlling, and recommended a glucose control target of TIR $>70 \%$, TBR $<4 \%$ and TBR $<1 \%$ for the majority of diabetes [7]. In 2020, TIR was further adopted by The ADA to be one of the target indexes of blood glucose control in diabetic patients [9]. In 2021, TIR was also included in the Chinese guidelines for the prevention and treatment of type 2 diabetes, and the target of TIR was recommended to be $\geq 70 \%$, but highly individualized.

Osteocalcin is a bone $\mathrm{Y}$ - carboxyglutamic acid (Gla) protein encoded by human osteocalcin gene-BGLAP, produced primarily by osteoblasts $[10,37]$, and it was conceived to take effects in skeleton cells exclusively when it was isolated in 1976s for the first time [11]. In bone metabolism, carboxylated osteocalcin is transmitted by vesicles in cells for secreting into the bone micro-environment, thus takes part in the mineralization of the bone, and participates in the bone formation directly [14]. In 2007, a new function of osteocalcin about regulating energy metabolism by acting as a hormone was discovered by Lee in Ocn-/- mice [12]. Mathieu showed osteocalcin can regulate the production of insulin by increasing the insulin genes-Ins1 and Ins2 expression, meanwhile $\beta$-cell proliferation was promoted on account of the expression of Cyclin D2 and Cdk4 induced by osteocalcin[23]. A series of studies have shown that osteocalcin could be one of the ways that bone metabolism affects glucose metabolism [35, 36], maybe it's a reason why defective bone formation and repairment were commonly seen in humans and animals with diabetes [38]. Therefore, the issue about whether a link between bone metabolism and glucose metabolism was existed deserves to be explored in diabetes. However, to the best of our knowledge, the correlation between osteocalcin and the progress of diabetes and insulin resistance remains unclear. The purpose of our study is to explore the interaction between serum osteocalcin and emerging glucose metrics including TIR.

\section{Research Design And Methods}

\subsection{Study Population}

There were 376 patients recruited from people who were diagnosed with T2DM according to the diagnostic criteria published by the WHO in 1999 in total[13], and hospitalized at the Department of Endocrinology and Metabolism of the Nan Fang Medical University Affiliated Jinling Hospital from March 2015 to April 2021. Patients who met the requirements about age $\geq 18$ years old, having a stable glucose- 
lowering treatment in the last three months were included in this trail. Subjects suffered from a hyperglycemic hyperosmolar state or severe hypoglycemic events within the previous 3 months; diabetic ketoacidosis; a history of cancer and mental diseases; severe kidney or liver dysfunction; combine with thyroid or parathyroid disease; diagnosed osteoporosis; therapy with drugs which can effect bone and calcium metabolism, such as vitamin $\mathrm{D}$, calcitonin, bisphosphonate or oestrogen were excluded. The local ethics committees approved this research in accordance with the Declaration of Helsinki.

\subsection{Anthropometric and Biochemical Assessments}

The basic characteristics including age composition, gender, duration of diabetes, height, weight were collected. Systolic blood pressure (SBP) and diastolic blood pressure (DBP) were measured with a precise sphyg- momanometers, and BMI was obtained according to the international calculation formula. Following an all-night fasting, a venous blood sample of participants was drawn by professional in the day before performing the CGM. HbA1c was detected with high performance liquid chromatography (HLC-723G8 Automatic glycosylated hemoglobin Analyzer, TOSOH, Japan). Biochemical indexes were measured by an automatic biochemical analyser (Model 7600 Series Automatic Analyzer, Hitachi, Japan). Circulating osteocalcin levels, Insulin and C-peptide concentrations were obtained by electricity Chemiluminescent immunoassay (IMMULITE 2000 XPi, Siemens, Germany). HOMA-IS and Homa- $\beta$ were calculated according to the standard calculation formula $\{$ HOMA- $\beta=20 \times$ fasting insulin (FINS $\mathrm{mIU} / \mathrm{L}) /[$ fasting serum glucose(FPG mmol/L)-3.5], HOMA-IS $=22.5 /[\mathrm{FPG}(\mathrm{mmol} / \mathrm{L}) \times \mathrm{FINS}(\mathrm{mIU} / \mathrm{L})]$ \}.

\subsection{CGM Parameters}

Patients were underwent CGM (Meiqi Corporation) for 3 consecutive days. Everyone was educated to aviod any strenuous activities that might affect blood glucose. All data was recorded completely, and EasyGV Version 9.0R2 from Oxford University was applied to assess the glucose control indicators. TIR was defined as the percentage of time that blood glucose levels remained between 3.9-10 mmol/L throughout the day, TBR represented the percentage of time that blood glucose $<3.9 \mathrm{mmol} / \mathrm{L}$ during 24 hours, time spent above $10.0 \mathrm{mmol} / \mathrm{L}$ in one day was TAR[5]. Glycemic variability like standard deviation (SD), glucose coefficient of variation (CV), low blood glucose index (LBGI), high blood glucose index (HBGI), mean amplitude of glucose excursions (MAGE), average daily danger range (ADDR), mean of daily differences (MODD) were calculated either.

\subsection{Statistical Analyses}

Patients were grouped into G1, G2, G3 and G4 on the account of the quartile of osteocalcin. We presented data with the mean $\pm S D$, median[25\% 75\%] depends on data types. Categorical variables were examined with a chi-squared test. The trends of the groups about the continuous and normally distributed variables were assessed with One-way ANOVA, while Kruskal-Wallis $\mathrm{H}$ test for abnormal. We carried out Spearman's rank correlation to assess the connection between osteocalcin and other variables. Multivariate linear regression analysis was coming into service to examine the independent associations of osteocalcin with 
CGM parameters after adjusting for age, diabetes duration, sex, BMI, SBP, DBP, TG, TC and other metrics. We considered $P<0.05$ as statistically significant. SPSS 25.0 software was employed to analysis.

\section{Results}

3.1 The comparison of clinical characteristics between groups

376 patients, including 235 men and 141 women, were grouped into four groups on the basis of the quartile of osteocalcin囚Table 1). The concentrations of osteocalcin were $8.73(7.509 .82) \mathrm{ng} / \mathrm{ml}$, $12.38(11.4313 .19) \mathrm{ng} / \mathrm{ml}, 15.10(14.5116 .00) \mathrm{ng} / \mathrm{ml}, 21.20(18.7026 .27) \mathrm{ng} / \mathrm{ml}$, from group 1 to 4 respectively. The differences of TIR between groups, divided according to the quartile of osteocalcin, were demonstrated in Figure 1. There were no statistically significant differences in gender composition, age, weight, BMI, diabetes duration, blood pressure between groups (respectively, p>0.05). Likely, no significant differences were discovered in biochemical measurements such as TC, TG, serum $K+$, serum $\mathrm{Ca}+$, Creatinine and total Vitamin D (Table 1).

3.2 The correlation between serum osteocalcin and glucose metrics

Compared with $\mathrm{G} 1$, patients in $\mathrm{G} 3$ and $\mathrm{G} 4$ tend to possess a lower level of TAR and $\mathrm{HbA} 1 \mathrm{C}$, as well as $M B G, S D, C V, H B G I, A D D R$ and MODD ( $p<0.05)$, on the contrary, TIR and LBGI were lower in G1. No significant differences were found in MAGE between groups $(P>0.05)$. Osteocalcin was positively correlated with TIR and HOMA-IS ( $r=0.227,0.192 \mathrm{P}<0.001)$, and a negative correlation was found between osteocalcin and TAR, HbA1C, whereas the relationship between osteocalcin and HOMA- $\beta$ was insignificant $(P=0.801)$. Likewise, INSOh, INSO.5h, blood glucose at all time points were inversely correlated with osteocalcin in circulation (Table 2). As for the index of glycemic variability, MBG, SD, HBGI, MODD, ADDR, CV and MAGE were all decreasing with the increase of serum osteocalcin level, and LGBI was positively correlated with osteocalcin $(r=0.133, p=0.01)$.

3.3 Multiple stepwise regression analysis of influencing factors of TIR ITAR\ HOMA- $\beta \square$ and HOMA-IS

Multiple stepwise regression analysis was applied to investigate the influencing factors of TIR, TBR $\square$ TAR, the result demonstrated that GluOh, Cp3h, duration, eGFR, osteocalcin, TG, age, ALT, HbA1C were independent contributors to TIR(Table 3). Meanwhile, GluOh, Cp3h, duration, eGFR, osteocalcin, TG, age, ALT, HbA1C were also independent factors of TAR (Table 4). Osteocalcin was found to be one of the influencing factors of HOMA-IS ( $\beta=0.188, p<0.001$ )(Table 6 ), but failed in HOMA- $\beta$ (Table 7).

\section{Discussion}

Bone metabolism is one of the critical components of body metabolism. In recent years, more and more evidence has accumulated that the skeleton can act as an organ of endocrine via secreting osteocalcin, and exert influence on energy metabolism by exerting a profound effect on glucose homeostasis, insulin sensitivity and fat metabolism [33,34]. Zhou et al. have demonstrated that osteocalcin was negatively 
correlated with blood glucose in diabetes, and osteocalcin level in diabetics was significantly lower than non-diabetics [45]. Among a population of 1867 aging males (75.3 $\pm 3.2 \mathrm{yrs}$ ) in the MrOS Sweden study, plasma osteocalcin was identified to be an independent negative predictor of plasma glucose $(p<0.001)$ [16]. In addition, even in patients who suffered from varying degrees of glucose tolerance区the number of subjects with normal glucose tolerance, impaired glucose tolerance and T2DM were 46, 52, 62, respectively), osteocalcin was suggested to be negatively correlated with glucose concentrations as usual [20]. The discoveries of this study are in keeping with trails performed previously. In our study, we grouped participants into four groups according to the quartile of osteocalcin. An inverse association was found between osteocalcin and patients' fasting and postprandial blood glucose after a standard meal . A higher osteocalcin level is accompanied by higher TIR, LBGI and lower HbA1C, TAR, HBGI. After adjusting for variables like age, sex, BMI, height, weight, diabetic duration, and eGFR, osteocalcin was found to be one of the independent factors of TIR and TAR. Spearman analysis found a positive correlation in serum osteocalcin level and TIR, LBGI, while other metrics including TAR, HbA1C, INSOh, INS0.5h, MBG, SD, MAGE, ADDR, MODD were negatively correlated with the circulation concentration of osteocalcin $(P<0.05)$. Multiple stepwise regression presented that osteocalcin was a positive independent factor of HOMA-IS. Overall, the outcome indicated that high osteocalcin level was an advantageous contributor for glycemic stability in type 2 diabetes.

Glucose variability is getting more attention in recent years, since a significant relationship between glycemic changing and vascular complica- tions, both micro- and macro-vascular, was observed in type 2 diabetes [46-48], and controlling blood glucose in target level strictly has been supposed to be one of the most important means to reduce the danger of both diabetic complications. $\mathrm{HbA} 1 \mathrm{C}$ was reported first by Rahbar in 1968, and was broadly used to estimate the fitness of diabetes treatment at the beginning [27]. Studies have proved that $\mathrm{HbA} 1 \mathrm{C}$ was closely relevant to complications of diabetes, both micro-vascular and cardiovascular, over the decades. The symbolic clinical trials including ACCORD, ADVANCE, and VADT had proved that better $\mathrm{HbA1c}$ levels was a protective factor to some micro-vascular complications in type 2 diabetes [50-52], while higher HbA1c levels was a more risky one. Until now, HbA1c is totally a gold criterion for appraising long-term glycemic control. However, the accuracy of $\mathrm{HbA} 1 \mathrm{C}$ measurement was impacted by many factors, including anemia, iron deficiency [5], ethnic groups and others [19]. Furthermore, $\mathrm{HbA} 1 \mathrm{c}$ can not reflect short period of blood glucose results and glucose excursions timely [49]. Therefore, much effort has been dedicated to trying to find a glycemic indicator other than $\mathrm{HbA} 1 \mathrm{C}$ as an alternative for optimal glycemic control assessment.

TIR was a key metric offered by CGM to analyse the quality of glucose controlling in recent years $[5,7]$. A large amount of studies has established that TIR is an indicator describing not only short- but also longterm glycemic control $[39,40]$. In addition, TIR was identified to relate to the threats of developing diabetes complications. A study conducted in 3262 diabetic patients has confirmed that an HbA1cindependent association existed between TIR and the prevalence of Diabetic Retinopathy at all stages [26]. Utilizing the DCCT data set, Beck and colleagues have found TIR correlates with the hazard ratio for diabetes complications, per $10 \%$ decrease in TIR, followed a $40 \%$ and $64 \%$ increased risk of retinopathy and microalbuminuria, separately[25]. More and more international organizations and guidelines have 
supported the application of TIR in clinical work, and TIR has already become a target index of glucose control in recent years.

In the present study, our result is consistent with the previous reports. And there are three possible mechanisms involved in the pathological process. First, osteocalcin stimulates the release of adiponectin, which can prevent beta-cell apoptosis [31, 32], and promote the regeneration of beta-cell through inducing the convey of HNF4A gene [41]. In adipose tissue, osteocalcin mediates the production of regulators which can regulate cell-cycle, such as Cyclin D1, D2, and Cdk4, which can affect insulin and proliferation of $\beta$-cells in human body $[12,23]$. Moreover, under-carboxycarlated osteocalcin can also motivate the release of glucagon-like peptide-1 (Glp-1), through interplay with the $\mathrm{G}$ protein-coupled receptor Gprc6a [21]. Hwang had demonstrated that higher serum uncarboxylated osteocalcin is associated with improved beta-cell function and lower HOMA-IR(the representative of insulin resistance) in 199 participants [18]. Second, osteocalcin was capable of alleviating endo- plasmic reticulum stress and restoring insulin sensitivity via PI3K/ Akt / NF-kB signaling pathway [43], increasing the generation of antioxidant system materials, including catalase, SOD-1, nuclear factor -E2 -related factor-2 and GPX1[44]. Third, by means of interacting with adipose tissue, osteocalcin can significantly increase the convey of Ucp1, Pgc1a[22], and decrease the secretion of pro-infammatory cytokines in adipose tissues [42]. Chin et al. suggested that osteocalcin is concerned with indicators of adiposity and high-density lipoprotein level in humans [17]. In our research, serum osteocalcin level was positively proportional to insulin sensitivity indicator- HOMA-IS. Multiple stepwise regression further proved that osteocalcin was an protective factor of HOMA-IS, indicated that the advantageous effect of osteocalcin on diabetes mellitus is partly realized by improving insulin sensitivity.

Several limitations existed in our study. Firstly, patients in the current study were performed the CGM for 3 days, instead of 10-14 days, which was recommended by the international common $[5,28]$. Secondly, osteocalcin comes in two forms, carboxylated and under-carboxylated osteocalcin [15], but we can only described total serum osteocalcin in this work. Finally, our study is an observational study, and the sample size is relatively small, a multi-center, larger scale and prospective study is needed to be carried out for further investigation.

In summary, circulating osteocalcin has a positively correlation with TIR in type 2 diabetes. Higher baseline osteocalcin levels was associated with a lower TAR in patients with T2DM. In our study, osteocalcin was an independent protective contributor to insulin sensitivity. Assessing serum levels of osteocalcin may provide further information for better management and therapy of T2DM.

\section{Abbreviations}

T2D: Type 2 diabetes; CGM: Continuous glucose monitoring; BMI: Body mass index; SBP: Systolic blood pressure; DBP: Diastolic blood pressure; TC: Total cholesterol; TG: Triglyceride; HbA1c: Hemoglobin A1c; TIR:time in range; TBR:time below range; TAR:time above range; CV:coefficient variation; SD:standard 
deviation; LBGI:low blood glucose index; HBGl:high blood glucose index;MAGE:mean amplitude of glucose excursions $₫$ ADDR:average daily danger range; MODD:mean of daily differences.

\section{Declarations}

\section{Acknowledgments}

The authors are very thankful to forward their gratitude to the data collectors, supervisor, study subjects for their cooperation.

\section{Author Contributions}

J.L., Y.W., P.Z., W.W., and Z.F. conceived and designed the research. J.L., P.Z., Y.Y., H.Z. and Z.Z. collected the data. J.L., Y.W., H.L., X.Y. and J.L. analyzed and interpreted the data. J.L. wrote the manuscript. B.L. and J.S. critically revised the manuscript and contributed to the discussion. J.L., Y.W., and P.Z. contributed equally to this work. All authors have read and approved the final manuscript.

\section{Funding}

This work was supported by the National Natural Science Foundation of China(81873174); Key Research and Development Plan Project of Jiangsu Province - Social Development Projects(BE2020701)

\section{Availability of data and materials}

The datasets used and/or analysed during the current study are available from the corresponding author on reasonable request.

\section{Ethics approval and consent to participate}

Approval was obtained from the ethics committee of Southern Medical University. The procedures used in this study adhere to the tenets of the Declaration of Helsinki. Informed consent was obtained from all individual participants included in the study.

\section{Consent for publication}

Not applicable.

\section{Competing interests}

There are no conflicts of interest.

\section{Author details}

${ }^{a}$ Department of Endocrinology, Jinling Hospital, Southern Medical University, Nanjing 210002, Jiangsu Province, China. 
${ }^{b}$ Department of Endocrinology, Jinling Hospital, School of Medicine, Nanjing University, Nanjing 210002, Jiangsu Province, China.

'Department of Endocrinology, Jinling Hospital, Nanjing Medical University, Nanjing 210002, Jiangsu Province, China.

*Jun Liu, Yinghua Wei and Pu Zang contributed equally to this work.

\#Corresponding authors at: Department of Endocrinology, Jinling Hospital, 305 East Zhongshan Road, Nanjing, Jiangsu Province, China.(Jiaqing Shao and Bin Lu)

Email: shaojiaqing@nju.edu.cn (Jiaqing Shao); yearinyearout@126.com (Bin Lu)

\section{Publisher's Note}

Springer Nature remains neutral with regard to jurisdictional claims in published maps and institutional affiliations.

\section{References}

1. Saeedi P, Petersohn I, Salpea P, et al. IDF Diabetes Atlas Committee. Global and regional diabetes prevalence estimates for 2019 and projections for 2030 and 2045: Results from the International Diabetes Federation Diabetes Atlas, 9th edition. Diabetes Res Clin Pract. 2019 Nov;157:107843.

2. GBD 2013 Mortality and Causes of Death Collaborators. Global, regional, and national age-sex specific all-cause and cause-specific mortality for 240 causes of death, 1990-2013: a systematic analysis for the Global Burden of Disease Study 2013. Lancet. 2015 Jan 10;385(9963):117 - 71.

3. Effect of intensive diabetes treatment on the development and progression of long-term complications in adolescents with insulin-dependent diabetes mellitus: Diabetes Control and Complications Trial. Diabetes Control and Complications Trial Research Group. J Pediatr. 1994 Aug;125(2):177-88.

4. Beyond A1C Writing Group. Need for regulatory change to incorporate beyond A1C glycemic metrics. Diabetes Care 2018;41: e92-4.

5. Danne T, Nimri R, Battelino T, et al. International consensus on use of continuous glucose monitoring. Diabetes Care 2017;40: 1631-40.

6. Bergenstal RM, Beck RW, Close KL,et al. Glucose management indicator (GMI): A new term for estimating A1C from continuous glucose monitoring. Diabetes Care 2018;41: 2275-80.

7. The Official Journal of ATTD Advanced Technologies \& Treatments for Diabetes Conference Madrid, Spain-February 19-22, 2020. Diabetes Technol Ther. 2020 Feb;22(S1):A1-A250.

8. Vigersky RA, McMahon C. The Relationship of Hemoglobin A1C to Time- in-Range in Patients with Diabetes. Diabetes Technol Ther 2019;21:81-85. 
9. American Diabetes Association. 6. Glycemic Targets: Standards of Medical Care in Diabetes-2020. Diabetes Care. 2020 Jan;43(Suppl 1):S66-S76.

10. Hauschka PV, Lian JB, Cole DE, et al. Osteocalcin and matrix Gla protein: vitamin K-dependent proteins in bone. Physiol Rev. 1989 Jul;69(3):990-1047.

11. Price PA,Poser JW,Raman N.Primary structure of the gamma- carboxyglutamic acid-containing protein from bovine bone.Proc Natl Acad Sci U S A 1976;73:3374-5.

12. Lee NK, Sowa H, Hinoi E, et al. Endocrine regulation of energy metabolism by the skeleton. Cell. 2007 Aug 10;130(3):456-69.

13. Alberti KG, Zimmet PZ. Definition, diagnosis and classification of diabetes mellitus and its complications. Part 1: diagnosis and classification of diabetes mellitus provisional report of a WHO consultation. Diabet Med 1998; 15: 539-553.

14. Hauschka PV, Lian JB, Cole DE, et al. Osteocalcin and matrix Gla protein: vitamin K-dependent proteins in bone. Physiol Rev 1989;69:990-1047.

15. Hill HS, Grams J, Walton RG, et al. Carboxylated and uncarboxylated forms of osteocalcin directly modulate the glucose transport system and inflammation in adipocytes. Horm Metab Res 2014;46:341-7.

16. Kindblom JM, Ohlsson C,Smith U,et al. Plasma osteocalcin is inversely related to fat mass and plasma glucose in elderly Swedish men. J Bone Miner Res Off J Am Soc Bone Miner Res 2009;24:785-91.

17. Chin KY, Ima-Nirwana S, Ramli ES, et al. Serum osteocalcin is significantly related to indices of obesity and lipid profile in Malaysian men. Int J Med Sci 2014;11:151-7.

18. Hwang YC, Jeong IK, Ahn KJ, et al. The uncarboxylated form of osteocalcin is associated with improved glucose tolerance and enhanced beta-cell function in middle-aged male subjects. Diabetes Metab Res Rev 2009;25:768-72.

19. Wolffenbuttel BH, Herman WH, Gross JL, et al. Ethnic differences in glycemic markers in patients with type 2 diabetes. Diabetes Care. 2013 Oct;36(10):2931-6.

20. Chen $X, W u Y, L i u L$, et al. Osteocalcin is inversely associated with glucose levels in middle-aged Tibetan men with different degrees of glucose tolerance. Diabetes Metab Res Rev 2014;30:476-82.

21. Mizokami A, Yasutake $Y$, Takeuchi $H$, et al. Osteocalcin induces release of glucagon-like peptide-1 and thereby stimulates insulin secretion in mice. PLoS One 2013;8:e57375.

22. Ferron M, McKee MD, Karsenty G. Intermittent injections of osteocalcin improve glucose metabolism and prevent type 2 diabetes in mice. Bone 2011;50:568-75.

23. Ferron M, Hinoi E, Karsenty G, et al. Osteocalcin differentially regulates beta cell and adipocyte gene expression and affects the development of metabolic diseases in wild-type mice. Proc Natl Acad Sci U S A 2008;105:5266-70.

24. Vigersky RA, McMahon C. The relationship of hemoglobin A1C to time-in-range in patients with diabetes. Diabetes Technol Ther 2019;21: 81-5. 
25. Beck RW, Bergenstal RM, Riddlesworth TD, et al. Validation of time in range as an outcome measure for diabetes clinical trials. Diabetes Care 2019;42: 400-5.

26. Lu J, Ma X, Zhu W, et al. Association of Time in Range, as Assessed by Continuous Glucose Monitoring, With Diabetic Retinopathy in Type 2 Diabetes. Diabetes care 2018;41:2370-2376.

27. Gebel E. The start of something good: the discovery of HbA1c and the American Diabetes Association samuel rahbar outstanding discovery award. Diabetes Care. 2012;35:2429-31.

28. Riddlesworth TD, Bergenstal RM, Lee S, et al. Optimal sampling duration for continuous glucose monitoring to determine long-term glycemic control. Diabetes Technol Ther 2018;20: 314-6.

29. Atkinson MA, Eisenbarth GS, Michels AW. Type 1 diabetes. Lancet 2014;383: 69-82.

30. Schade DS, Lorenzi GM, Braffett BH, et al. DCCT/EDIC Research Group. Hearing impairment and type 1 diabetes in the diabetes control and complications trial/ epidemiology of diabetes interventions and complications (DCCT/EDIC) cohort. Diabetes Care 2018;41: 2495-501.

31. Yamauchi T, Kamon J, Kadowaki T. The fat-derived hormone adiponectin reverses insulin resistance associated with both lipoatrophy and obesity. Nat Med. 2001 Aug;7(8):941-6.

32. Kubota N, Terauchi $Y$, Noda T. Disruption of adiponectin causes insulin resistance and neointimal formation. J Biol Chem. 2002 Jul 19;277(29):25863-6.

33. DiGirolamo DJ, Clemens TL, Kousteni S. The skeleton as an endocrine organ. Nat Rev Rheumatol. 2012 Nov;8(11):674-83.

34. Karsenty G, Oury F. Biology without walls: the novel endocrinology of bone. Annu Rev Physiol. 2012;74:87-105.

35. Yoshikawa Y, Kode A, Xu L, et al. Genetic evidence points to an osteocalcin-independent influence of osteoblasts on energy metabolism. J Bone Miner Res. 2011 Sep;26(9):2012-25.

36. Yao Q, Yu C, Zhang X, et al. Wnt/ $\beta$-catenin signaling in osteoblasts regulates global energy metabolism. Bone. 2017 Apr;97:175-183.

37. Puchacz E, Lian JB, Stein GS, et al. Chromosomal localization of the human osteocalcin gene. Endocrinology. 1989 May;124(5):2648-50.

38. Thrailkill KM, Lumpkin CK Jr, Bunn RC, et al. Is insulin an anabolic agent in bone? Dissecting the diabetic bone for clues. Am J Physiol Endocrinol Metab. 2005 Nov;289(5):E735-45.

39. Vigersky RA, ShinJ JB, et al. The Comprehensive Glucose Pentagon: A Glucose-Centric Composite Metric for Assessing Glycemic Control in Persons With Diabetes. J Diabetes Sci Technol 2018;12:114-23.

40. Augstein P, Heinke P, et al. Q-Score: development of a new metric for continuous glucose monitoring that enables stratification of antihyperglycaemic therapies. BMC Endocr Disord. 2015 May 1;15:22.

41. Scheja L, Heeren J. The endocrine function of adipose tissues in health and cardiometabolic disease. Nat Rev Endocrinol. 2019 Sep;15(9):507-524.

42. Hill HS, Grams J, Walton RG, et al. Carboxylated and uncarboxylated forms of osteocalcin directly modulate the glucose transport system and inflammation in adipocytes. Horm Metab Res. 2014 
May;46(5):341-7.

43. Zhou B, Li H, Xu L, et al. Osteocalcin reverses endoplasmic reticulum stress and improves impaired insulin sensitivity secondary to diet-induced obesity through nuclear factor-kB signaling pathway. Endocrinology. 2013 Mar;154(3):1055-68.

44. Du J, Zhang M, Lu J, et al. Osteocalcin improves nonalcoholic fatty liver disease in mice through activation of Nrf2 and inhibition of JNK. Endocrine. 2016 Sep;53(3):701-9.

45. Zhou M, Ma X, Li H, et al. Serum osteocalcin concentrations in relation to glucose and lipid metabolism in Chinese individuals. Eur. J. Endocrinol. 2009; 161: 723-9.

46. Hemmingsen B, Lund SS, Hemmingsen $C$, et al. Targeting intensive glycaemic control versus targeting conventional glycaemic control for type 2 diabetes mellitus. Cochrane Database Syst Rev. 2013 Nov 11;(11):CD008143.

47. The Diabetes Control and Complications Trial Research Group. The effect of intensive treatment of diabetes on the development and progression of long-term complications in insulin-dependent diabetes mellitus. N Engl J Med 1993;329:977-986.

48. Stratton IM, Adler Al, Neil HAW, et al. Association of glycaemia with macrovascular and microvascular complications of type 2 diabetes(UKPDS 35): prospective observational study.BMJ 2000;321:405-412.

49. Runge AS, Kennedy L, Brown AS, et al. Does time-in-range matter? Perspectives from people with diabetes on the success of current therapies and the drivers of improved outcomes. Clin Diabetes 2018;36: 112-9.51.

50. Action to Control Cardiovascular Risk in Diabetes Follow-On (ACCORDION) Eye Study Group, Action to Control Cardiovascular Risk in Diabetes FollowOn (ACCORDION) Study Group. Persistent effects of intensive glycemic control on retinopathy in type 2 diabetes in the action to control cardiovascular risk in diabetes (ACCORD) follow-on study. Diabetes Care. 2016;39:1089-100.

51. Heller SR; ADVANCE Collaborative Group. A summary of the ADVANCE Trial. Diabetes Care. 2009 Nov;32 Suppl 2(Suppl 2):S357-61.

52. Agrawal L, Azad N, VADT Study Group, et al. Long-term follow-up of intensive glycaemic control on renal outcomes in the Veterans Affairs Diabetes Trial (VADT). Diabetologia. 2018 Feb;61(2):295299.

\section{Tables}

Table 1. Characteristics of study participants by quartiles of Osteocalcin 


\begin{tabular}{|c|c|c|c|c|c|}
\hline Variables & G1 & G2 & G3 & G4 & $\mathbf{P}$ \\
\hline number & 94 & 94 & 94 & 94 & \\
\hline Male/Female & M 60 F 34 & M 62 F 32 & M 59 F 35 & M 54 F 40 & \\
\hline $\begin{array}{l}\text { Osteocalcin } \\
(\mathrm{ng} / \mathrm{ml})\end{array}$ & $8.73(7.509 .82)$ & $\begin{array}{l}12.38 \bigotimes 11.43 \\
13.19 \rrbracket\end{array}$ & $\begin{array}{l}15.10 \rrbracket 14.51 \\
16.00 \rrbracket\end{array}$ & $\begin{array}{l}21.20(18.70 \\
26.27)\end{array}$ & $<0.001$ \\
\hline TBR (\%) & $0.00(0.000 .00)$ & $\begin{array}{l}0.00 \otimes 0.00 \\
0.00 \rrbracket\end{array}$ & $\begin{array}{l}0.00 \otimes 0.00 \\
0.04 \rrbracket\end{array}$ & $0.00(0.000 .47)$ & 0.71 \\
\hline TIR (\%) & $\begin{array}{l}53.94(34.01 \\
70.93)\end{array}$ & $\begin{array}{l}58.43 \rrbracket 40.47 \\
76.11 \rrbracket\end{array}$ & $\begin{array}{l}68.64 \rrbracket 34.76 \\
86.93 \rrbracket\end{array}$ & $\begin{array}{l}72.20(45.55 \\
85.93)\end{array}$ & 0.001 \\
\hline TAR (\%) & $\begin{array}{l}45.24(29.07 \\
64.29)\end{array}$ & $\begin{array}{l}41.57 \rrbracket 23.15 \\
59.44)\end{array}$ & $\begin{array}{l}30.86 \rrbracket 13.03 \\
62.84 \rrbracket\end{array}$ & $\begin{array}{l}26.74(13.32 \\
53.07)\end{array}$ & 0.001 \\
\hline age(years) & $55.68 \pm 11.43$ & $56.49 \pm 11.13$ & $53.27 \pm 3.80$ & $55.30 \pm 12.84$ & 0.403 \\
\hline Weight (Kg) & $70.41 \pm 12.30$ & $70.25 \pm 12.20$ & $71.7 \pm 12.63$ & $68.15 \pm 12.69$ & 0.288 \\
\hline $\operatorname{High}(\mathrm{m})$ & $1.66 \pm 0.08$ & $1.66 \pm 0.08$ & $1.68 \pm 0.09$ & $1.67 \pm 0.09$ & 0.467 \\
\hline BMI (kg/m2) & $25.37 \pm 3.62$ & $25.03 \pm 3.21$ & $25.08 \pm 3.27$ & $24.74 \pm 3.70$ & 0.669 \\
\hline $\begin{array}{l}\text { Creatinine } \\
\text { (umol/L) }\end{array}$ & $57.16 \pm 16.34$ & $58.02 \pm 13.35$ & $56.27 \pm 14.87$ & $59.24 \pm 17.45$ & 0.615 \\
\hline $\begin{array}{l}\text { duration } \\
\text { (years) }\end{array}$ & $7.00(2.0015 .00)$ & $\begin{array}{l}8.00(2.75 \\
15.00)\end{array}$ & $\begin{array}{l}6.00 \rrbracket 2.00 \\
12.00 \rrbracket\end{array}$ & $6.00(1.0011 .00)$ & 0.419 \\
\hline $\begin{array}{l}\text { SBP } \\
(\mathrm{mmHg})\end{array}$ & $\begin{array}{l}130.00(127.75 \\
145.00 \rrbracket\end{array}$ & $\begin{array}{l}130(124.75 \\
140.00)\end{array}$ & $\begin{array}{l}130 \otimes 129.50 \\
140.00 \bigotimes\end{array}$ & $\begin{array}{l}130.00(120.00 \\
138.50)\end{array}$ & 0.499 \\
\hline $\begin{array}{l}\text { DBP } \\
(\mathrm{mmHg})\end{array}$ & $\begin{array}{l}78.00 \otimes 75.00 \\
86.25)\end{array}$ & $\begin{array}{l}79.00(75.00 \\
85.25)\end{array}$ & $\begin{array}{l}79.00 \otimes 75.00 \\
87.50)\end{array}$ & $\begin{array}{l}78.00(74.00 \\
82.25)\end{array}$ & 0.705 \\
\hline $\begin{array}{l}\mathrm{K} \\
(\mathrm{mmol} / \mathrm{L})\end{array}$ & $3.82 \pm 0.37$ & $3.8 \pm 0.33$ & $3.86 \pm 0.32$ & $3.84 \pm 0.29$ & 0.581 \\
\hline $\begin{array}{l}\mathrm{Ca} \\
(\mathrm{mmol} / \mathrm{L})\end{array}$ & $2.21 \pm 0.12$ & $2.24 \pm 0.12$ & $2.21 \pm 0.10$ & $2.19 \pm 0.11$ & 0.053 \\
\hline $\begin{array}{l}\text { TC } \\
(\mathrm{mmol} / \mathrm{L})\end{array}$ & $4.42 \pm 1.14$ & $4.63 \pm 1.07$ & $4.56 \pm 0.95$ & $4.71 \pm 1.04$ & 0.297 \\
\hline $\begin{array}{l}\text { TG } \\
(\mathrm{mmol} / \mathrm{L})\end{array}$ & $1.53 \rrbracket 1.102 .32 \rrbracket$ & $\begin{array}{l}1.61(1.12 \\
2.28)\end{array}$ & $\begin{array}{l}1.50(1.10 \\
2.35)\end{array}$ & 1.44(1.01 1.98) & 0.602 \\
\hline
\end{tabular}




\begin{tabular}{|c|c|c|c|c|c|}
\hline HbA1C (\%) & $9.25 \pm 1.73$ & $9.00 \pm 1.98$ & $8.62 \pm 2.21$ & $8.49 \pm 1.94$ & 0.045 \\
\hline Vit D (ng/ml) & $24.11 \pm 6.84$ & $25.56 \pm 6.64$ & $25.15 \pm 6.86$ & $23.73 \pm 6.27$ & 0.218 \\
\hline $\begin{array}{l}\text { MBG } \\
(\mathrm{mmol} / \mathrm{L})\end{array}$ & $10.35 \pm 2.02$ & $9.89 \pm 2.12$ & $9.53 \pm 2.49$ & $9.21 \pm 1.79$ & 0.002 \\
\hline SD & $2.86 \pm 1.01$ & $2.59 \pm 0.99$ & $2.35 \pm 0.88$ & $2.44 \pm 0.97$ & 0.008 \\
\hline CV & $0.28 \pm 0.08$ & $0.28 \pm 0.10$ & $0.24 \pm 0.06$ & $0.26 \pm 0.08$ & $<0.001$ \\
\hline LBGI & $0.37 \rrbracket 0.001 .74 \rrbracket$ & $\begin{array}{l}0.50 \rrbracket 0.05 \\
1.50 \rrbracket\end{array}$ & $\begin{array}{l}0.37(0.01 \\
1.03)\end{array}$ & $0.74(0.211 .81)$ & 0.043 \\
\hline HBGI & $\begin{array}{l}10.26 \bigotimes 7.08 \\
14.40 \rrbracket\end{array}$ & $\begin{array}{l}9.61 \rrbracket 6.07 \\
13.82 \rrbracket\end{array}$ & $\begin{array}{l}7.13(3.61 \\
13.82)\end{array}$ & 6.74(3.75 12.87) & 0.002 \\
\hline $\begin{array}{l}\text { MAGE } \\
(\mathrm{mmol} / \mathrm{L})\end{array}$ & $5.30 \pm 2.03$ & $4.78 \pm 1.76$ & $4.75 \pm 1.72$ & $4.89 \pm 1.69$ & 0.171 \\
\hline $\begin{array}{l}\text { ADDR } \\
(\mathrm{mmol} / \mathrm{L})\end{array}$ & $\begin{array}{l}27.27 \rrbracket 20.61 \\
37.24 \rrbracket\end{array}$ & $\begin{array}{l}25.31 \rrbracket 18.53 \\
32.40 \rrbracket\end{array}$ & $\begin{array}{l}20.84(13.91 \\
32.64)\end{array}$ & $\begin{array}{l}21.29(13.15 \\
31.86)\end{array}$ & 0.001 \\
\hline $\begin{array}{l}\text { MODD } \\
(\mathrm{mmol} / \mathrm{L})\end{array}$ & 2.44(1.68 3.37) & $\begin{array}{l}2.38(1.76 \\
3.52)\end{array}$ & $\begin{array}{l}2.07(1.35 \\
2.56)\end{array}$ & $2.05(1.43$ 3.16) & 0.003 \\
\hline
\end{tabular}

Data are presented as means \pm SD, median (25\% and $75 \%$ interquartiles), and count (percentages) according to characteristics of distribution. Between-group, comparisons were conducted by One-way ANOVA, Kruskal- Wallis $\mathrm{H}$ test and the chi-squared test.

Abbreviation: BMI body mass index, TC total cholesterol, TG triglycerides, SBP systolic blood pressure, DBP diastolic blood pressure, $\mathrm{HbA} 1 \mathrm{c}$ hemoglobin A1C, TIR time in range, TBR time below range, TAR time above range, CV coefficient variation, SD standard deviation, LBGI low blood glucose index, HBGI high blood glucose index, MAGE mean amplitude of glucose excursions, ADDR average daily danger range, MODD mean of daily differences.

* Significant difference with group $1(P<0.05)$.

\# Significant difference with group 2(P<0.05).

* Significant difference with group $3(P<0.05)$.

Table 2. Spearman Partial Correlation Among Osteocalcin and Selected CGM Metrics. 


\begin{tabular}{|c|c|}
\hline Variables & osteocalcin \\
\hline \multirow[t]{2}{*}{ TIR } & $r=0.227$ \\
\hline & $P<0.001$ \\
\hline \multirow[t]{2}{*}{ TBR } & $r=0.068$ \\
\hline & $P=0.189$ \\
\hline \multirow[t]{2}{*}{ TAR } & $r=-0.229$ \\
\hline & $P<0.001$ \\
\hline \multirow[t]{2}{*}{$\mathrm{HbA} 1 \mathrm{C}$} & $r=-0.143$ \\
\hline & $P=0.006$ \\
\hline \multirow[t]{2}{*}{ INSOh } & $r=-0.169$ \\
\hline & $P=0.001$ \\
\hline \multirow[t]{2}{*}{ INS0.5h } & $r=-0.115$ \\
\hline & $P=0.03$ \\
\hline \multirow[t]{2}{*}{ INS1h } & $r=-0.081$ \\
\hline & $P=0.128$ \\
\hline \multirow[t]{2}{*}{ INS2h } & $r=-0.016$ \\
\hline & $P=0.762$ \\
\hline \multirow[t]{2}{*}{ INS3h } & $r=-0.027$ \\
\hline & $P=0.603$ \\
\hline \multirow[t]{2}{*}{ CpOh } & $r=-0.064$ \\
\hline & $P=0.219$ \\
\hline \multirow[t]{2}{*}{ Cp0.5h } & $r=-0.039$ \\
\hline & $P=0.448$ \\
\hline \multirow[t]{2}{*}{ Cp1h } & $r=0.004$ \\
\hline & $P=0.935$ \\
\hline \multirow[t]{2}{*}{ Cp2h } & $r=0.048$ \\
\hline & $P=0.351$ \\
\hline \multirow[t]{2}{*}{ Cp3h } & $r=0.045$ \\
\hline & $P=0.389$ \\
\hline
\end{tabular}

Page 16/21 


\begin{tabular}{|c|c|}
\hline \multirow[t]{2}{*}{ GLuOh } & $r=-0.185$ \\
\hline & $P<0.001$ \\
\hline \multirow[t]{2}{*}{ GLu0.5h } & $\mathrm{r}=-0.252$ \\
\hline & $P<0.001$ \\
\hline \multirow[t]{2}{*}{ GLu1h } & $\mathrm{r}=-0.238$ \\
\hline & $P<0.001$ \\
\hline \multirow[t]{2}{*}{ GLu2h } & $r=-0.216$ \\
\hline & $P<0.001$ \\
\hline \multirow[t]{2}{*}{ GLu3h } & $r=-0.185$ \\
\hline & $P<0.001$ \\
\hline \multirow[t]{2}{*}{ HOMA- $\beta$} & $r=-0.013$ \\
\hline & $P=0.801$ \\
\hline \multirow[t]{2}{*}{ HOMA-IS } & $r=0.192$ \\
\hline & $P<0.001$ \\
\hline \multirow[t]{2}{*}{ MBG } & $\mathrm{r}=-0.21$ \\
\hline & $P<0.001$ \\
\hline \multirow[t]{2}{*}{ SD } & $r=-0.157$ \\
\hline & $P=0.002$ \\
\hline \multirow[t]{2}{*}{ CV } & $r=-0.076$ \\
\hline & $P=0.142$ \\
\hline \multirow[t]{2}{*}{ LBGI } & $r=0.133$ \\
\hline & $P=0.01$ \\
\hline \multirow[t]{2}{*}{ HBGI } & $r=-0.21$ \\
\hline & $P<0.001$ \\
\hline \multirow[t]{2}{*}{ MODD } & $r=-0.162$ \\
\hline & $P=0.002$ \\
\hline \multirow[t]{2}{*}{ MAGE } & $r=-0.092$ \\
\hline & $P=0.078$ \\
\hline ADDR & $r=-0.215$ \\
\hline
\end{tabular}

Page 17/21 
Abbreviation: HbA1c hemoglobin A1C, TIR time in range, TBR time below range, TAR time above range, INS insulin, Cp C-peptide, Glu postprandial glucose, CV coefficient variation, SD standard deviation, LBGI low blood glucose index, HBGI high blood glucose index, MAGE mean amplitude of glucose excursions, ADDR average daily danger range, MODD mean of daily differences.

Table 3. Multiple stepwise regression analysis of influencing factors of TIR.

\begin{tabular}{|llllllll|}
\hline & \multicolumn{2}{l}{$\begin{array}{l}\text { Unstandardized } \\
\text { Coefficients }\end{array}$} & \multicolumn{2}{l}{$\begin{array}{l}\text { Standardized } \\
\text { Coefficients }\end{array}$} & \multicolumn{3}{l|}{$\begin{array}{l}\text { 95.0\% Confidence } \\
\text { Interval for B }\end{array}$} \\
& B & Std. Error & Beta & $t$ & $P$ & $\begin{array}{l}\text { Lower } \\
\text { Bound }\end{array}$ & $\begin{array}{c}\text { Upper } \\
\text { Bound }\end{array}$ \\
\hline (Constant) & 117.31 & 10.44 & & 11.236 & 0 & 96.762 & 137.859 \\
\hline Glu0h & -2.279 & 0.381 & -0.292 & -5.988 & 0 & -3.028 & -1.53 \\
\hline Cp3h & 1.425 & 0.346 & 0.206 & 4.121 & 0 & 0.744 & 2.105 \\
\hline duration & -0.592 & 0.16 & -0.187 & -3.695 & 0 & -0.907 & -0.277 \\
\hline eGFR & -0.119 & 0.035 & -0.176 & -3.425 & 0.001 & -0.188 & -0.051 \\
\hline osteocalcin & 0.532 & 0.197 & 0.127 & 2.7 & 0.007 & 0.144 & 0.92 \\
\hline TG & -1.869 & 0.63 & -0.146 & -2.968 & 0.003 & -3.109 & -0.63 \\
\hline Age & -0.324 & 0.111 & -0.155 & -2.913 & 0.004 & -0.542 & -0.105 \\
\hline ALT & -0.171 & 0.074 & -0.109 & -2.305 & 0.022 & -0.317 & -0.025 \\
\hline HbA1C & -0.824 & 0.388 & -0.101 & -2.122 & 0.035 & -1.588 & -0.06 \\
\hline
\end{tabular}

Dependent Variable: TIR

Table 4. Multiple stepwise regression analysis of influencing factors of TAR. 


\begin{tabular}{|llllllll|}
\hline & \multicolumn{2}{l}{$\begin{array}{l}\text { Unstandardized } \\
\text { Coefficients }\end{array}$} & \multicolumn{2}{l}{$\begin{array}{l}\text { Standardized } \\
\text { Coefficients }\end{array}$} & \multicolumn{3}{l|}{$\begin{array}{l}\text { 95.0\% Confidence } \\
\text { Interval for B }\end{array}$} \\
& B & Std. Error & Beta & $\mathrm{t}$ & $\mathrm{P}$ & $\begin{array}{l}\text { Lower } \\
\text { Bound }\end{array}$ & $\begin{array}{c}\text { Upper } \\
\text { Bound }\end{array}$ \\
\hline (Constant) & -18.383 & 10.531 & & -1.746 & 0.082 & -39.11 & 2.345 \\
\hline Glu0h & 2.317 & 0.384 & 0.294 & 6.036 & 0 & 1.562 & 3.073 \\
\hline Cp3h & -1.381 & 0.349 & -0.198 & -3.96 & 0 & -2.068 & -0.695 \\
\hline duration & 0.57 & 0.162 & 0.178 & 3.525 & 0 & 0.252 & 0.887 \\
\hline eGFR & 0.124 & 0.035 & 0.18 & 3.51 & 0.001 & 0.054 & 0.193 \\
\hline osteocalcin & -0.556 & 0.199 & -0.132 & -2.794 & 0.006 & -0.947 & -0.164 \\
\hline TG & 1.915 & 0.635 & 0.149 & 3.013 & 0.003 & 0.664 & 3.165 \\
\hline Age & 0.311 & 0.112 & 0.148 & 2.779 & 0.006 & 0.091 & 0.532 \\
\hline ALT & 0.172 & 0.075 & 0.109 & 2.291 & 0.023 & 0.024 & 0.319 \\
\hline HbA1C & 0.866 & 0.392 & 0.105 & 2.21 & 0.028 & 0.095 & 1.637 \\
\hline
\end{tabular}

Dependent Variable: TAR

Table 5. Multiple stepwise regression analysis of influencing factors of TBR

\begin{tabular}{|llllllll|}
\hline & \multicolumn{2}{l}{$\begin{array}{l}\text { Unstandardized } \\
\text { Coefficients }\end{array}$} & \multicolumn{2}{l}{$\begin{array}{l}\text { Standardized } \\
\text { Coefficients }\end{array}$} & \multicolumn{3}{l|}{$\begin{array}{l}95.0 \% \text { Confidence Interval } \\
\text { for B }\end{array}$} \\
& B & Std. Error & Beta & $\mathrm{t}$ & & $\begin{array}{l}\text { Lower } \\
\text { Bound }\end{array}$ & $\begin{array}{l}\text { Upper } \\
\text { Bound }\end{array}$ \\
\hline (Constant) & -1.836 & 0.775 & & -2.369 & 0.018 & -3.361 & -0.311 \\
\hline Ca & 0.502 & 0.207 & 0.138 & 2.426 & 0.016 & 0.095 & 0.909 \\
\hline Age & 0.026 & 0.011 & 0.129 & 2.267 & 0.024 & 0.003 & 0.048 \\
\hline
\end{tabular}

Dependent Variable: TBR

Table 6. Multiple stepwise regression analysis of influencing factors of HOMA-IS. 


\begin{tabular}{|llllllll|}
\hline & \multicolumn{2}{l}{$\begin{array}{l}\text { Unstandardized } \\
\text { Coefficients }\end{array}$} & \multicolumn{2}{l}{$\begin{array}{l}\text { Standardized } \\
\text { Coefficients }\end{array}$} & \multicolumn{3}{l|}{$\begin{array}{l}\text { 95.0\% Confidence } \\
\text { Interval for B }\end{array}$} \\
& B & Std. Error & Beta & $\mathrm{t}$ & & $\begin{array}{l}\text { Lower } \\
\text { Bound }\end{array}$ & $\begin{array}{l}\text { Upper } \\
\text { Bound }\end{array}$ \\
\hline (Constant) & 1.861 & 0.328 & & 5.673 & 0 & 1.215 & 2.506 \\
\hline BMI & -0.026 & 0.01 & -0.157 & -2.753 & 0.006 & -0.045 & -0.008 \\
\hline osteocalcin & 0.018 & 0.005 & 0.188 & 3.54 & 0 & 0.008 & 0.028 \\
\hline TG & -0.046 & 0.016 & -0.156 & -2.831 & 0.005 & -0.078 & -0.014 \\
\hline ALT & -0.006 & 0.002 & -0.156 & -2.777 & 0.006 & -0.01 & -0.002 \\
\hline SBP & -0.004 & 0.002 & -0.138 & -2.6 & 0.01 & -0.008 & -0.001 \\
\hline
\end{tabular}

Dependent Variable: HOMA-IS

Table 7. Multiple stepwise regression analysis of influencing factors of HOMA- $\beta$.

\begin{tabular}{|llllllll|}
\hline & \multicolumn{2}{l}{$\begin{array}{l}\text { Unstandardized } \\
\text { Coefficients }\end{array}$} & \multicolumn{2}{l}{$\begin{array}{l}\text { Standardized } \\
\text { Coefficients }\end{array}$} & \multicolumn{3}{l|}{$\begin{array}{l}\text { 95.0\% Confidence Interval } \\
\text { for B }\end{array}$} \\
& B & Std. Error & Beta & t & & B & Std. Error \\
\hline (Constant) & 367.381 & 106.059 & & 3.464 & 0.001 & 158.662 & 576.101 \\
\hline TC & -51.553 & 21.917 & -0.135 & -2.352 & 0.019 & -94.685 & -8.421 \\
\hline
\end{tabular}

Dependent Variable: HOMA- $\beta$

\section{Figures}




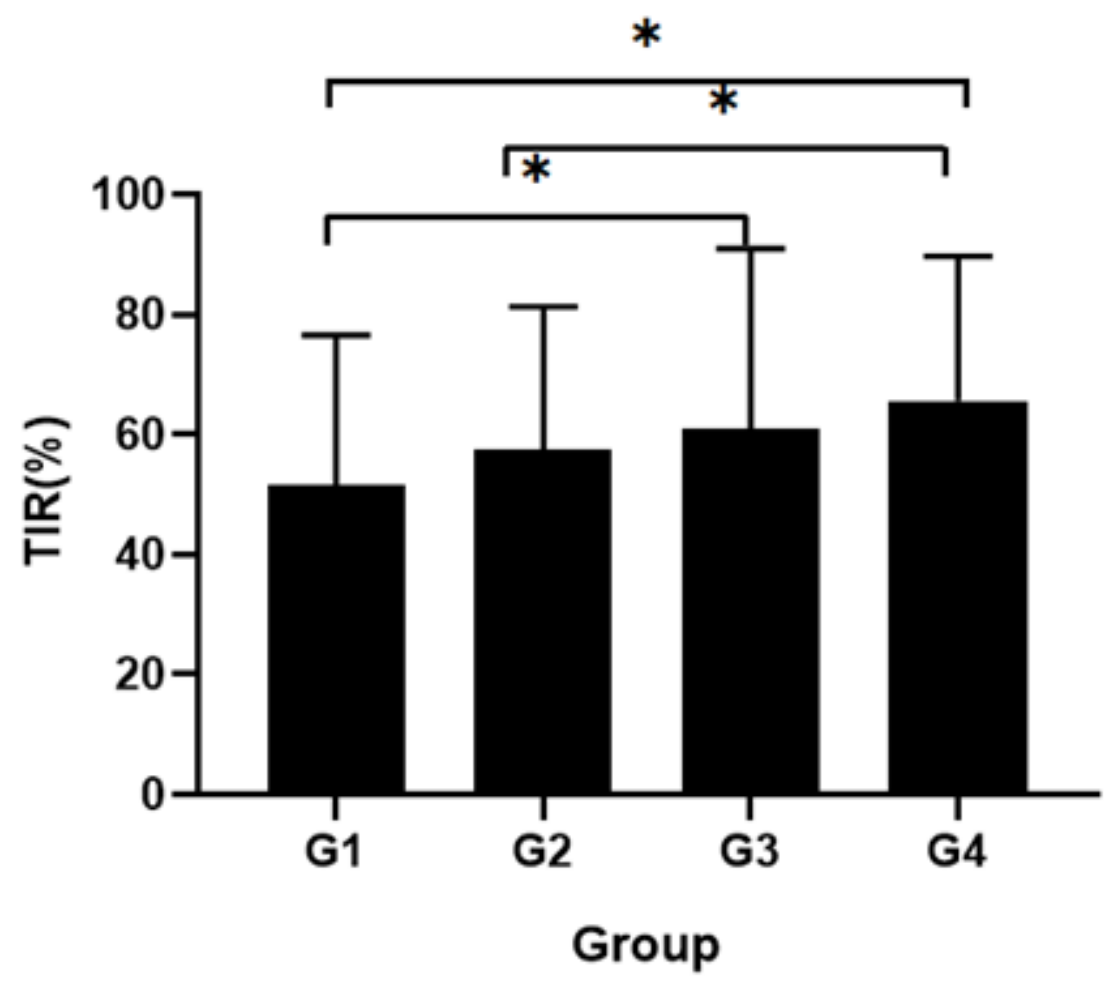

Figure 1

TIR of groups which were divided by quarters(G1-G4) of osteocalcin level. The statistical significance of comparisons between groups indicated as the following: $\mathbb{\triangle} \mathrm{P}=0.001$ 